\title{
APLIKASI SEGMENTASI JANTUNG
}

\author{
Linda Salma Angreani, Amin Hariyadi, Dwi Safitri \\ Teknik Informatika Uin Maulana Malik Ibrahim Malang
}

\begin{abstract}
Abstrak -Secara umum penentuan kontur maupun diameter jantung masih dilakukan secara manual, diamati dan di tentukan oleh radiolog. Hasilnya sangat di pengaruhi oleh kemampuan maupun pengalaman dari ahli radiologi, karena faktor subyektifitas dalam pemeriksaan jantung pada citra x-ray rongga dada oleh radiolog, maka diperlukan alternatif metode yang mampu memberikan analisis yang lebih baik (obyektif) dan dapat dipergunakan dalam berbagai hal. Pada penelitian ini menggunakan metode Active Shape Model untuk segmentasi Jantung dari hasil citra $\mathrm{x}$-ray rongga dada.

Segmentasi jantung pada citra $x$-ray thorax menggunakan Active Shape Model dengan landmark 5, 10 dan 15 diperoleh hasil : akurasi 85.84\% (untuk landmark 15 point), sensitifitas $77.38 \%$ (untuk landmark 15 point), dan spesifitas $91.39 \%$ (untuk landmark 10 point) dengan tingkat akurasi tersebut menunjukkan bahwa metode ini dapat digunakan untuk segmentasi bagian jantung pada citra $x$-ray rongga dada.
\end{abstract}

\section{PENDAHULUAN}

Rongga dada merupakan bagian dari struktur tubuh manusia yang cukup penting karena di dalamnya terdapat organ-organ vital, yaitu paru-paru dan jantung. Ganguan pada organ ini bisa berimplikasi pada organ vital lainnya, dalam hal ini jantung, demikian juga sebaliknya.

Dalam dunia medis, salah satu cara untuk melihat ketidaknormalan atau penyakit dalam rongga dada didasarkan pada gejala klinis dan pemeriksaan X-raythorax (Fatchoerochman, 2010). Penggunaan X-ray karena biayanya lebih terjangkau, Xraythorax pada orang dewasa memperlihatkan tulang-tulang thorax termasuk costae, diaphragma, cor, pulmo, clavicula, scapula, dan jaringan lunak dinding thorax. Organ thorax terbagi menjadi dua bagian dengan mediastinum di tengahnya (Dewanto, 2008).

Pendeteksian dini terhadap ketidaknormalan suatu organ sangat diperlukan karena dengan diketahuinya penyebab awal suatu penyakit maka proses perawatan yang sesuai akan lebih mudah dilakukan. Untuk mengetahui ketidaknormalan organ-organ pada rongga dada diperlukan analisis dan interpretasi yang akurat.

Identifikasi kelainan atau penyakit organ jantung dapat dilakukan melalui ukuran diameter terpanjang paru-paru. Perhitungan ini sangat berguna untuk mendeteksi penyakit jantung terutama yang ditandai

dengan adanya pembesaran ukuran jantung.
Metode pengukuran ini disebut dengan CTR (Cardiothoracic Ratio). CTR menggunakan perbandingan antara panjang diameter terpanjang paru-paru dengan diameter terpanjang jantung. Dengan mengetahui ukuran perbandingan tersebut, maka kelainan atau penyakit organ bisa diidentifikasi sejak dini.pada model perhitungan CTR terlebih dahulu kita harus mengetahui jarak maksimum jantung dari citra XRay melalui proses segmentasi secara manual terhadap objek jantung pada citra.

Kesulitan yang dialami adalah segmentasi manual ini biasanya hanya dilakukan oleh seorang yang ahli dalam bidang radiologi. Untuk membantu dan mempermudah proses segmentasi ini, diperlukannya aplikasi yang memilikiakurasi serta kecepatan yang baik untuk mengolah dan memproses citra X-Ray, maka hal ini menjadi salah satu pertimbangan serta solusi lain agar segmentasi dapat dilakukan dengan mudah. Penelitan yang dilakukan ini mengambil tema Aplikasi segmentasi objek jantung pada citra X-Ray thorax menggunakan metode Active Shape Model, metode ini diimplementasikan untuk mendeteksi tepi objek jantung dalam citra X-Ray thorax. Hal ini dilakukan untuk dapat mempermudah kita dalam mendapatkan kontur jantung dari objek citra X-Ray. 


\section{PEMBAHASAN.}

\section{A. Model}

Pembuatan perangkat lunak menggunakanmodel Waterfall, yang terdiri dari tahapan sebagai berikut :

1. Rekayasa Sistem

2. Tahap ini merupakan kegiatan pengumpulan data sebagai pendukung pembangunan system, menentukan ke arah mana aplikasi ini akan dibangun.

3. Analisis Sistem

4. Perancangan Sistem

5. Pengkodean Sistem

6. Pengujian Sistem

7. Pemeliharaan Sistem

8. Umpan Balik

\section{B. Analisis Segmentasi Jantung}

Langkah-langkah dalam melakukan segmentasi jantung didasarkan pada hasil segmentasi paru-paru yang sudah dilakukan, adapun tahapan dalam melakukan segmentasi jantung sebagai berikut :

1.Input citra asli (foto thoraxposteroanterior).

2. Segmentasi dengan menggunakan GAC, pencarian garis tepi obyek (data matrik).

3. Konversi citra biner ini berbasis matrik kedalam citra berbasis vektor. (data matrik menjadi data vektor).

4. Menentukan titik letak keberadaan Jantung.

5. Aproksimasi garis tepi jantung atas.

6. Aproksimasi garis tepi jantung bawah.

7. Menentukan empat garis tepi Jantung.

8. Menggabung ke empat garis tepi jantung.

\section{Desain}

Desain tahapan proses segmentasi jantung digambarkan pada gambar 1 dibawah ini :

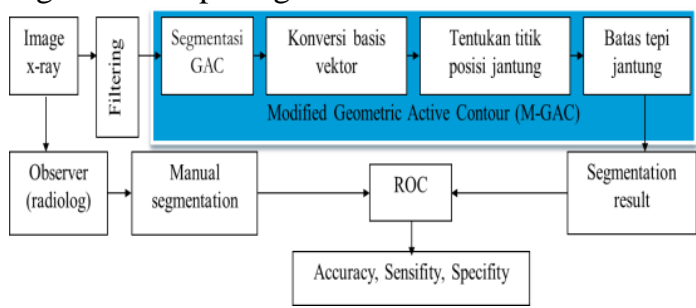

Gambar 1. Tahapan Proses Segmentasi Jantung

Untuk Desain antar muka aplikasi seperti pada gambar 2,3, 4 dan 5 dibawah ini.

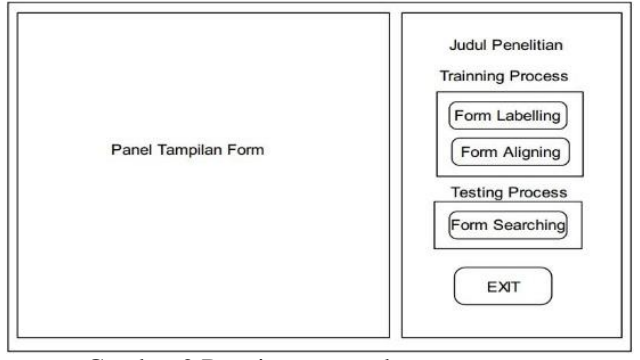

Gambar 2 Desain antar muka menu utama

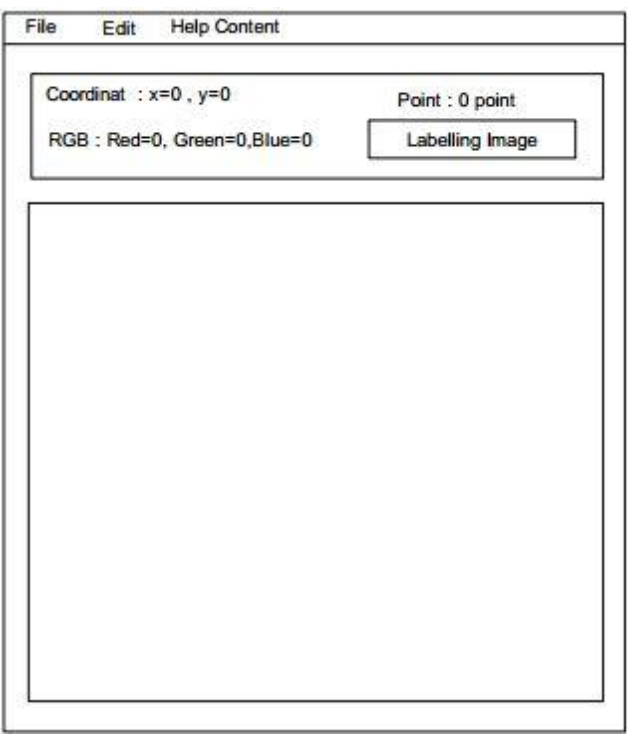

Gambar 3 Desain antarmuka Labelling Training

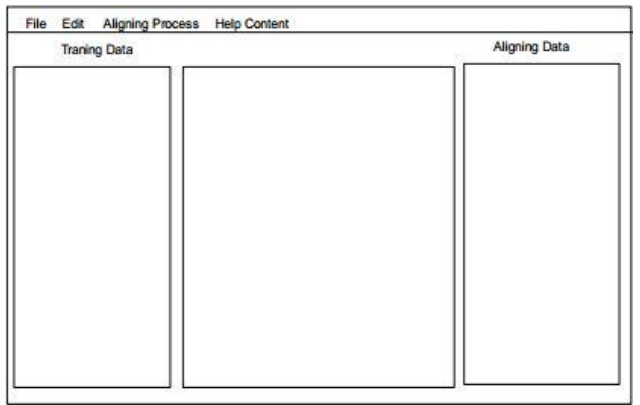

Gambar 4 Desain antarmuka Aligning Shape

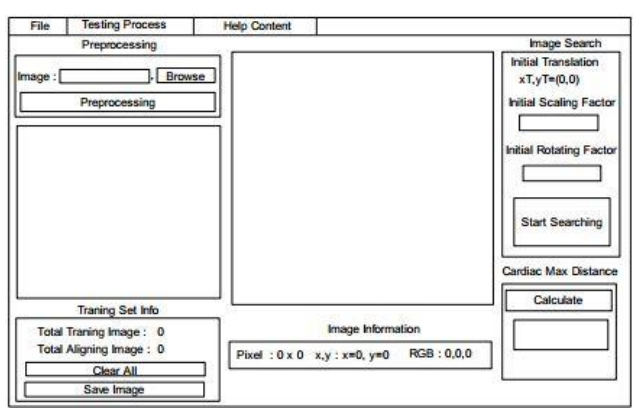

Gambar 5 Desain antarmuka Image Search 


\section{Implementasi}

Berikut implementasi antarmuka dalam segmentasi jantung

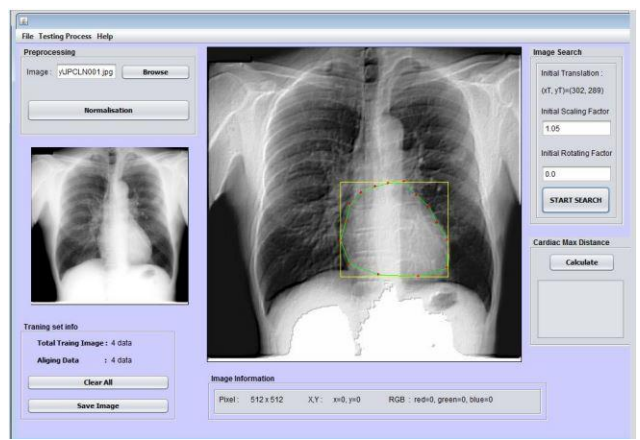

Gambar 6. Implementasi antarmuka Image Search

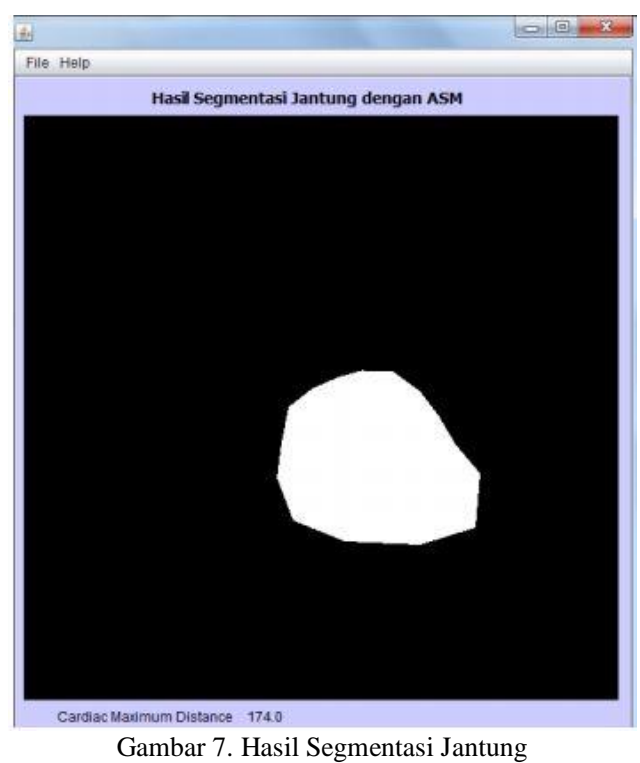

III.

Pengujian Sistem.

Proses PengujianAplikasi Segmentasi Jantung menggunakan nilai TP, TN, FP dan FN untuk mendapatkan nilai dari akurasi, sensitifitas dan seperti pada gambar 8 .

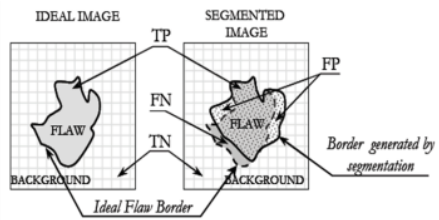

Formulasi matrix dari TP,TN,FP,FN

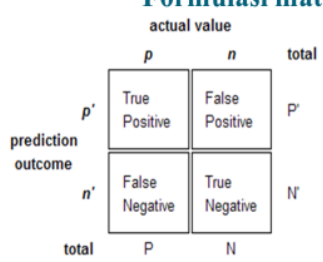

Accuray : $: A c C=\frac{(I P+T N)}{(P+N)}$

Senstivity $: T P R=\frac{T P}{P}=\frac{T P}{(T P+F N)}$

Specifity $\quad: S P C=\frac{T N}{N}=\frac{T N}{(F P+T N)}=1-F P R$

Gambar 8. Perhitungan Proses Pengujian
Hasil pengujian sistem terdapat pada tabel 1 dibawah ini.

Tabel1. Hasil Pengujian

\begin{tabular}{|c|c|c|c|c|}
\hline No & $\begin{array}{c}\text { Jumlah } \\
\text { Landmark }\end{array}$ & Akurasi & Sensitifitas & Spesifitas \\
\hline 1 & 5 point & 79.47 & 69.54 & 85.19 \\
\hline 2 & 10 point & 84.33 & 74.17 & 91.39 \\
\hline 3 & 15 point & 85.84 & 77.38 & 90.85 \\
\hline
\end{tabular}

\section{KESIMPULAN DAN SARAN}

\section{A. Kesimpulan}

Dari hasil implementasi dan ujicoba dilakukan dalam proses segmentasi jantung pada citra $\mathrm{X}$-ray thorax menggunakan landmark 5, 10 dan 15, maka didapatkan:

1. Hasil rata-rata akurasi sebesar $85.84 \%$ (landmark 15 point), dengan sensitifitas atau kemampuan $77.38 \%$ (Landmark 15 Point), sedangkan hasil spesifisitas tertinggi, yang menunjukkan kemampuan metode untuk melakukan segmentasi selain objek jantung didapatkan pada landmark 10 sebesar $91.39 \%$.

2. Semakin banyak jumlah landmark yang digunakan pada proses traning set akan meningkatkan tingkat akurasi dari data citra testing hasil pengujian.

4.2 Saran

Untuk pengembangan penelitian dimasa akan datang, maka dapat dilakukan beberapa hal berikut :

1.Penggunaan preprocessing pengembangan aplikasi selanjutnya dapat juga dilakukan jenis preprocessing lain untuk membantu proses segmentasi.

2. Proses inisialisasi awal pada citra testing dapat dilakukan sedekat mungkin dengan objek pada citra.

\section{DAFTAR PUSTAKA}

[1] Ch, Marvin, Agus.P. 2007. Pengolahan Citra Digital menggunakan Matlab.Penerbit Informatika. Bandung

[2] Cootes, T.F., Taylor,C.J,. 1994. Active Shape Models- their Training and Application, Computer Vision and Image Understanding. Vol. 61, No. 1, pp. 38-59.

[3] Cootes, T.F. 2000. An Intruduction to Active Shape Model . In Ed.R.Baldock and J.Graham, Image Processing and 
Analysis, pp 223-248.. Oxford University Press.

[4] Corr, Peter. 2010. Mengenali Pola foto-foto Diagnostik. PENERBIT BUKU KEDOKTERAN (EGC). Jakarta

[5] Hariyadi, Amin 2014,Pengukuran Semi-Otomatis Cardio Thoracic Ratio (CTR) menggunakan Geometri Kontur Aktif, Disertasi, Program Doktor Jurusan Teknik Elektro Fakultas Teknologi Indutri Institut Teknologi Sepuluh Nopember Surabaya
[6] Hamarneh, Ghassan. 1998. Active Shape Model, Modelling Shape Variation and Gray Level Information and an Application to Image Search and Classification. Department of Signals and Systems, Imaging and Image Analysis Group, Chalmers University of Technology, Goteborg, Sweden.

[7] Mardiyah, Ainatul. 2012. Metode Segmentasi Paru-Paru Dan Jantung Pada Citra X-Ray Thorax. Tesis. Jurusan Program Studi S2 Ilmu Komputer, Fakultas Matematika Dan Ilmu Pengetahuan Alam, Universitas Gadjah Mada. Yogyakarta. 